Case report

\title{
GASTRIC DILATATION AND VOLVULUS IN BROWN BEAR (URSUS ARCTOS)
}

\author{
MARINKOVIĆ Darko ${ }^{1 *}$, ÖZVEGY Jòzsef ${ }^{2}$, ANIČIĆ Milan ${ }^{1}$, VUČIĆEVIĆ Ivana ${ }^{1}$, \\ NEŠIĆ Slađan ${ }^{1}$, KUKOLJ Vladimir ${ }^{1}$ \\ ${ }^{1}$ Department of Pathology, Faculty of Veterinary Medicine, University of Belgrade, Bulevar \\ oslobodjenja 18, Belgrade, Serbia; ${ }^{2}$ Belgrade Zoo Garden, Mali Kalemegdan 8, Belgrade, Serbia
}

(Received 29 December 2015; Accepted 15 June 2016)

Gastric dilatation and volvulus is a life-threatening condition characterized by rapid accumulation of food and gases that cause displacement and distension of the stomach. The large and giant, deep-chested breeds of dogs are at higher risk for developing the gastric dilatation and volvulus. Uncommonly, it can also develop in cats, but it is also described in free-range polar bears.

A case of gastric dilatation and volvulus in a brown bear (Ursus arctos) is described in this paper. This case was characterized by lack of any previous symptoms, sudden death, as well as macroscopic findings during necropsy - twisted distended stomach, congested displaced spleen and necrotic gastric wall. According to the available data this is the first described case report of the gastric dilatation and volvulus in brown bear (Ursus arctos).

Key words: brown bear, Ursus arctos, gastric dilatation and volvulus

\section{INTRODUCTION}

Gastric dilatation and volvulus represents the combination of displacement and distension of the stomach due to accumulation of food and gases. It occurs relatively common in large and giant, deep-chested breeds of dogs [1], and uncommonly in cats [2], but it is also described in polar bears [3]. In polar bears omental torsion is also described [4]. Simple gastric dilatation is described in horses [5] and rabbits [6]. Predisposing factors for developing gastric dilatation and volvulus include: anatomic features such as deep thorax, increased laxity of the hepatogastric ligament, but also postprandial activity, particularly vigorous movement, aerophagia, large amount of distending gas, food and fluid as well as obstruction of the pylorus and cardia [7].

Similar factors can also be included in the developement of gastric dilatation and volvulus in bears. Most bear species, and among them brown bear (Ursus arctos), are opportunistic omnivores and sometimes consume large quantities of food. They have a simple stomach that is well adapted to periodic gorging. This is of most

\footnotetext{
*Corresponding author: e-mail: darko@vet.bg.ac.rs
} 
importance for captive bears whose diet has to be controlled to avoid overfeeding and development of obesity. Bears are teritorial and food-defensive animals and this can lead to intraspecies conflicts followed by vigorous activity, especially during the feeding, and during the mating also [8].

The purpose of this paper was to describe a case of gastric dilatation and volvulus of a captive brown bear.

\section{CASE PRESENTATION}

In September 2015 twenty five years old, male brown bear (Ursus arctos) suddenly died in the Belgrade Zoo. It showed no previous symptoms prior death and was found dead within the closed part (den) of his habitat. Necropsy was performed. The carcass was in good body condition, but the abdomen was very distended. Gross changes in the abdominal cavity were evident. The stomach was extremely distended, rotated about $180^{\circ}$ in clockwise direction as viewed from the caudal aspect, and filled almost the whole cranial part of the abdominal cavity, pushing the diaphragm in the cranial direction (Fig 1a,b), the lungs were collapsed. Gastric blood vessels were extremely marked and petechial hemorrhage were present on the serosal surface in the region of the great gastric curvature. The congested spleen was displaced beneath the dilated stomach, turned slightly to the right side of the abdomen. Haemoperitoneum was also present. The stomach, duodenum, pancreas and spleen could be repositioned into their anatomic sites with difficulty. The spleen was enlarged, about $70 \mathrm{~cm}$ in length, weighing $5 \mathrm{~kg}$ and was engorged with blood (Fig 1b, 2). The teeth of this bear were in bad condition. Two canine teeth were broken with exposed pulp (Fig 3), incisor teeth showed signs of wearing, and dental calculus was also present. Diffuse petechial hemorrhages of the pancreas and diaphragm were noted. Necrotic changes were noted on the mucosal surface of the stomach (Fig. 4). Stenosis of the aortic ring, endocardiosis of the bicuspid valve and subsequent hypertrophy of the left ventricle of the myocardium were present (Fig. 5). The right kidney had multiple cysts.
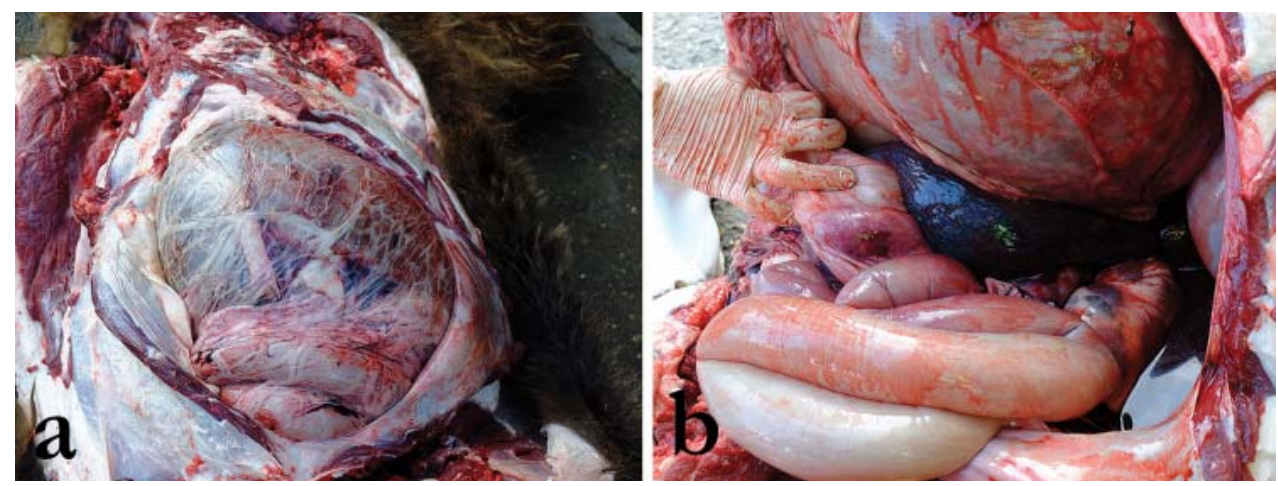

Figure 1. Macroscopic changes in the abdomen of the brown bear with gastric dilatation and volvulus. a) distended stomach, b) torsion of the stomach and displacement of the spleen 


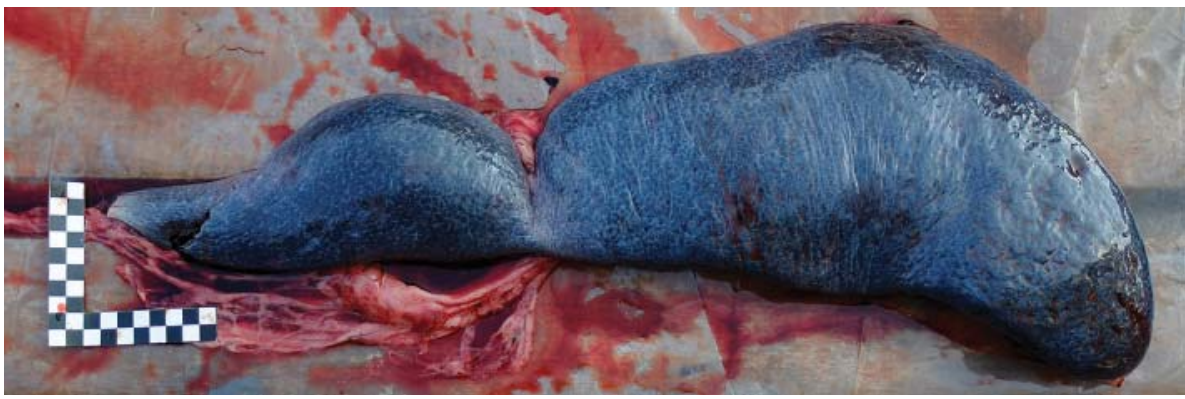

Figure 2. Enlargement of the spleen of the brown bear with gastric dilatation and volvulus

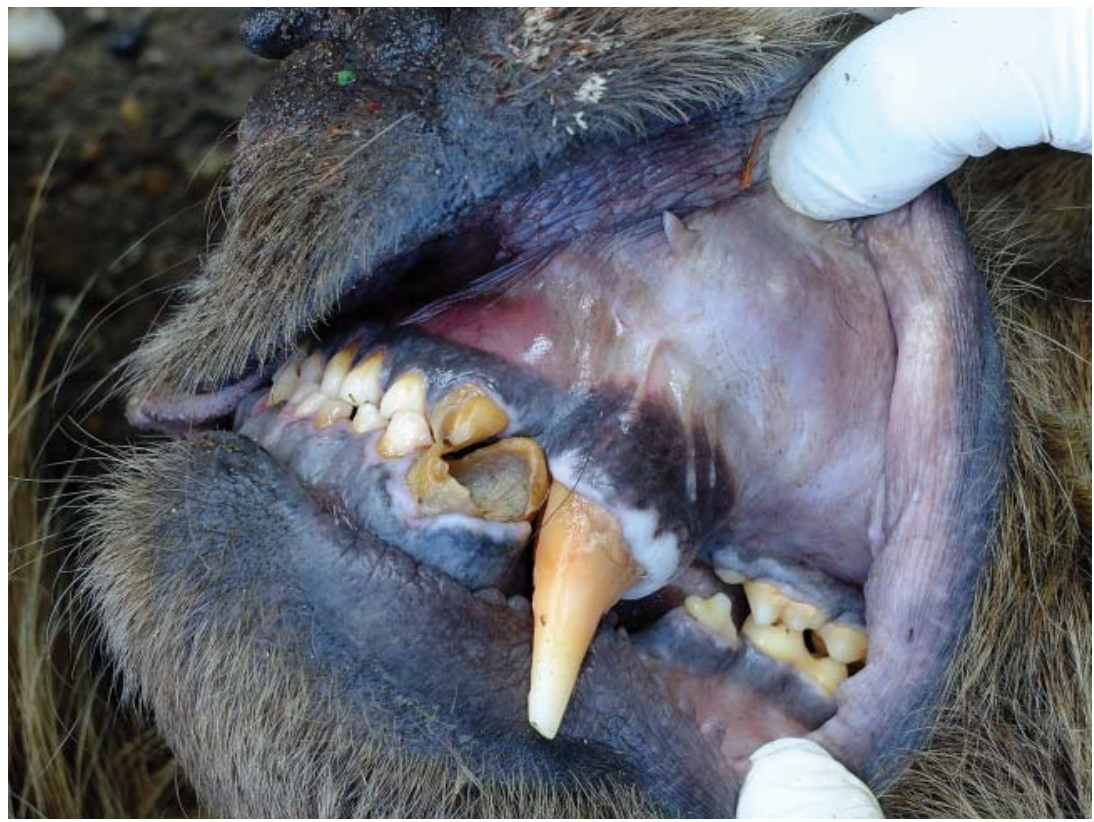

Figure 3. Macroscopic changes of the teeth and gastric mucosa of the brown bear - broken canine teeth with exposed pulp

Histopathologic examination revealed marked congestion of the spleen and necrosis of the pancreas. Also, myodegeneration of the cardiac muscle as well as degenerative changes (atherosclerosis and calcification) of the myocardial small blood vessels were noted. Also, hemorrhages in the cortex of the adrenal glands and hepatic telangiectasiae were noted. The kidneys showed signs of degenerative changes of the tubulocytes and interstitial nephritis. 


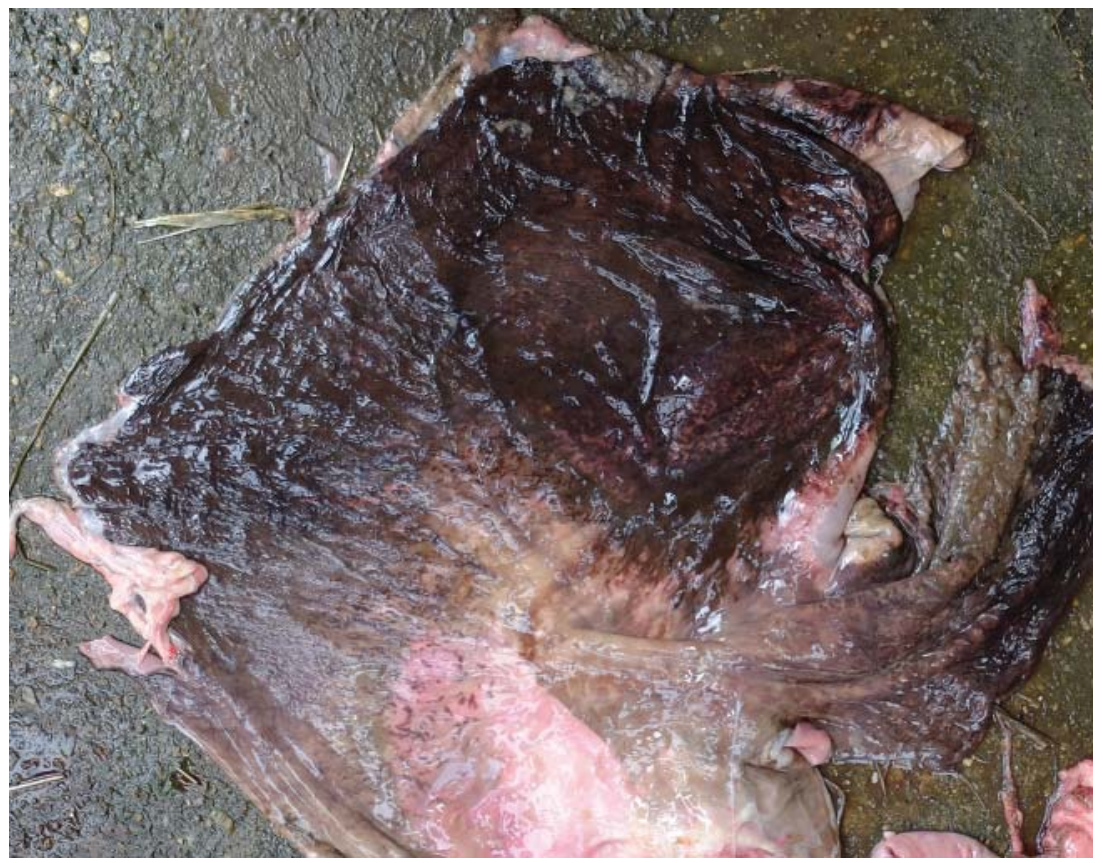

Figure 4. Macroscopic changes of the gastric mucosa of the brown bear - necrotic gastric mucosa

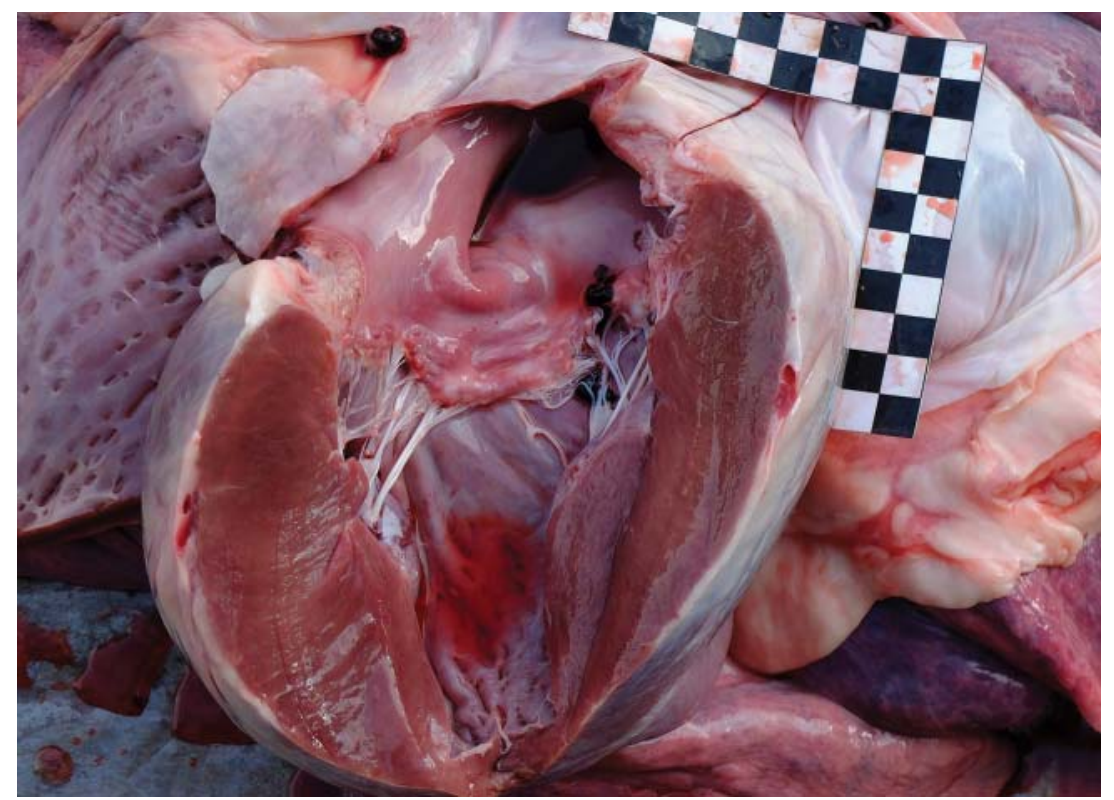

Figure 5. Left ventricular hypertrophy of the myocardium 


\section{DISCUSSION}

In our case, anamnestic data - lack of any previous symptoms, sudden onset of death, as well as macroscopic findings during necropsy - twisted distended stomach, congested displaced spleen and necrotic gastric wall were highly suggestive for gastric dilatation and volvulus.

There is only one reported case of gastric dilatation and volvulus in a polar bear (Ursus maritimus) [3]. These authors described pathomorphological findings in an adult male free-range polar bear, found dead in Alaska. The bear had a twisted and distended stomach and a congested and displaced spleen. These findings, along with lack of other important pathologic conditions were indicative that the animal died of gastric dilatation and volvulus.

Different predisposing factors for developing gastric dilatation and volvulus in dogs can be listed and they include: anatomic features such as deep thorax, increased laxity of the hepatogastric ligament, but also postprandial activity, particularly vigorous movement, aerophagia, large amount of distending gas, food and fluid as well as obstruction of the pylorus and cardia [7]. Similar to dogs, these factors can also be included in the development of gastric dilatation and volvulus in bears. Bears have a simple stomach that is well adapted to periodic gorging, and can perform increased activity, especially during interspecies relations (food defensive behavior and mating) [3,8,9]. Also bears are good chewers, and problems with teeth, as seen in our case, common in captive and free-ranging bears, can be also predisposing factors in developing gastrointestinal dysfunction as well as different other health issues [10,11].

During volvulus the stomach rotates about the esophagus (which becomes obstructed) in a clockwise direction up to $360^{\circ}$, viewed from the caudal aspect. Venous infarction of the gastric mucosa leads to necrosis of the mucosa and also other layers of the gastric wall. Exact changes were noted in the bear in our case. The dilated stomach leads to increasing of intra-abdominal pressure which impinges on the diaphragm and compromises respiration. Enlarged, congested and displaced spleen was noted in the bear in our case, which is in consistency with the findings of other authors which suggest that gastric volvulus is commonly combined with splenic displacement and congestion [12]. Volvulus and pressure by the distended stomach obstruct the gastroduodenal and splenic veins which result in decreased venous return through the portal vein and caudal vena cava, causing reduced perfusion of intra-abdominal organs, reduced cardiac output, and subsequent circulatory shock. Shock is also assisted with cardiac arrhythmias which occur as a result of release of myocardial depressant factor (MDF) from an ischemic pancreas, and with myocardial necrosis, resulting from ischemia. Systemic circulatory shock can also be complicated if different other health issues, or if the animal is aged [13]. The bear described our case was 25 years old, which is an average life span for brown bears, so this animal could be considered as a geriatric. Beside this, necropsy and histopathological findings showed that this bear had cardiac issues - stenosis of the aortic ring, endocardiosis of the bicuspid valve, left ventricular 
hypertrophy, myodegeneration of the cardiac muscle as well as degenerative changes (atherosclerosis and calcification) of the myocardial small blood vessels.

We can conclude that pathomorphological findings were significant for the diagnosis of the gastric dilatation and volvulus. To our knowledge, there are no existing reports of gastric dilatation and volvulus in the free-range or captive brown bear (Ursus arctos).

\section{Acknowledgements}

This study was supported by the Ministry of Education, Science and Technological Development of the Republic of Serbia, Grant No TR 31087.

\section{Authors' contributions}

MD participated in case design, performed necropsy, carried out histopathological examination and translated the manuscript, OJ provides anamnestic and clinical data and took photography during the necropsy, AM performed necropsy, carried out histopathological examination, VI and NS carried out histopathological examination and literature research, KV participated in case design and helped to draft the manuscript. All authors read and approved the final manuscript.

\section{Declaration of conflicting interests}

The author(s) declared no potential conflicts of interest with respect to the research, authorship, and/or publication of this article.

\section{REFERENCES}

1. Monnet E: Gastric dilatation-volvulus syndrome in dogs. Vet Clin North Am Small Anim Pract. 2003, 33: 987-1005.

2. Bredal WP, Eggertsdóttir AV, Austefjord O: Acute gastric dilatation in cats: a case series. Acta Vet Scand. 1996, 37: 445-451.

3. Amsturp SC, Nielsen CA: Acute gastric dilatation and volvulus in free-living polar bear. J Wildl Dis. 1989, 25: 601-604.

4. Mendez-Angulo JL, Funes FJ, Trent AM, Willette M, Woodhouse K, Renier AC: Omental torsion in a captive polar bear (Ursus maritimus). J Zoo Wildl Med. 2014, 45: 169-172.

5. Kiper ML, Traub-Dargatz J, Curtis CR: Gastric rupture in horses: 50 cases (1979-1987). J Am Vet Med Assoc. 1990, 196: 333-336.

6. Harcourt-Brown FM: Gastric dilation and intestinal obstruction in 76 rabbits.Vet Rec. 2007, 161:409-414.

7. Glickman LT, Glickman NW, Schellenberg DB, Raghavan M, Lee T: Non-dietary risk factors for gastric dilatation-volvulus in large and giant breed dogs. J Am Vet Med Assoc. 2000, 217: 1492-1499. 
8. Ramsay MA, Stirling I: On the mating system of polar bears. Can J Zool. 1986, 64: 2142 2151

9. Collins DM: Ursidae. In Miller RE, Fowler ME: vol. 8. 2015, Fowler's Zoo and Wild Animal Medicine, pp. 498-508.

10. Wenker CJ, Stich H, Müller M, Lussi A: A retrospective study of dental conditions of captive brown bears (Ursus arctos spp.) compared with free-ranging Alaskan grizzlies (Ursus arctos horribilis). J Zoo Wildl Med. 1999, 30(2): 208-221.

11. Strömquist A, Fahlman A, Arnemo JM, Pettersson A: Dental and periodontal health in free-ranging Swedish brown bears (Ursus arctos). J Comp Pathol. 2009, 141(2-3): 170-176.

12. Millis DL, Nemzek J, Riggs C, Walshaw R: Gastric dilatation-volvulus after splenic torsion in two dogs. J Am Vet Med Assoc. 1995, 207: 314-315.

13. Brown CC, Baker DC, Barker IK: Alimentary system. In: Jubb, Kennedy and Palmer's Pathology of domestic animals, $5^{\text {th }}$ edition, volume 2, Saunders Ltd.

\title{
DILATACIJA I VOLVULUS ŽELUCA KOD MRKOG MEDVEDA (URSUS ARCTOS)
}

\author{
MARINKOVIĆ Darko, ÖZVEGY Jòzsef, ANIČIĆ Milan, VUČIĆEVIĆ Ivana, \\ NEŠIĆ Slađan, KUKOLJ Vladimir
}

Dilatacija i volvulus želuca je stanje opasno po život koje se karakteriše brzim nakupljanjem hrane i gasova dovodeći do pomeranja i rastezanja želuca. Psi velikih i gigantskih rasa sa dubokim grudnim košem su pod većim rizikom za razvoj ovog poremećaja. Veoma retko, dilatacija i torzija želuca može nastati i kod mačaka, a opisan je i slučaj kod polarnog medveda.

U ovom radu je prikazan slučaj dilatacije i volvulusa želuca kod mrkog medveda (Ursus arctos). Izostanak simptoma, iznenadno uginuće, kao i makroskopski nalaz tokom obdukcije - uvrnut, proširen želudac, izmeštena kongestirana slezina i nekrotičan zid želuca su glavne karakteristike slučaja. Prema raspoloživim podacima ovo je prvi prikaz slučaja dilatacije i volvulusa želuca kod mrkog medveda (Ursus arctos). 